\title{
20) 43050
}

\section{CONTRACTOR REPORT}

SAND93-7076

Unlimited Release

UC -276

\section{Low Cost Photovoltaic Inverters} Incorporating Application-Specific Integrated Circuits .

George A. O'Sullivan, P.E.

Abacus Controls Inc.

Somerville, New Jersey

Joseph A. O'Sullivan, Ph.D

Washington University

St. Louis, Missouri

Prepared by Sandia National Laboratories Albuquerque, New Mexico 87185 and Livermore, California 94550 for the United States Department of Energy under Contract DE-AC04-76DP00789

Printed October 1993 
Issued by Sandia National Laboratories, operated for the United States Department of Energy by Sandia Corporation.

NOTICE: This report was prepared as an account of work sponsored by an agency of the United States Government. Neither the United States Government nor any agency thereof, nor any of their employees, nor any of their contractors, subcontractors, or their employees, makes any warranty, express or implied, or assumes any legal liability or responsibility for the accuracy, completeness, or usefulness of any information, apparatus, product, or process disclosed, or represents that its use would not infringe privately owned rights. Reference herein to any specific commercial product, process, or service by trade name, trademark, manufacturer, or otherwise, does not necessarily constitute or imply its endorsement, recommendation, or favoring by the United States Government, any agency thereof or any of their contractors or subcontractors. The views and opinions expressed herein do not necessarily state or reflect those of the United States Government, any agency thereof or any of their contractors.

Printed in the United States of America. This report has been reproduced directly from the best available copy.

Available to DOE and DOE contractors from

Office of Scientific and Technical Information

PO Box 62

Oak Ridge, TN 37831

Prices available from (615) 576-8401, FTS 626-8401

Available to the public from

National Technical Information Service

US Department of Commerce

5285 Port Royal Rd

Springfield, VA 22161

NTIS price codes

Printed copy: A3

Microfiche copy: A01 


\section{DISCLAIMER}

Portions of this document may be illegible electronic image products. Images are produced from the best available original document. 
SAND93-7076

Unlimited Release

Printed October 1993

\title{
LOF-COST PHOTOVOLTAIC INVERTERS \\ INCORPORATING APPLICATION-SPECIFIC
}

INTEGRATED CIRCUITS

\author{
George A. O'Sullivan, P.E. \\ Abacus Controls Inc. \\ Somerville, New Jersey \\ Joseph A. O'Sullivan, Ph.D. \\ Washington University \\ st. Louis, Missouri
}

\begin{abstract}
The positive impact of designing a power conditioner control system for photovoltaic applications with an application-specific integrated circuit (ASIC) as the main control element was demonstrated with detailed computer simulations in Phase I of a two phase Small Business Innovative Research Grant issued by the U S Department of Energy. Completion of the design, building and testing of three prototypes using different power semiconductors was successfully accomplished in Phase II.

The power rating for the residential utility intertied sunverter ${ }^{\circledR}$ Model $753-4-200$ is $5 \mathrm{~kW}$. For specifications on this unit and other members of the product family see Appendix A. A stand-alone inverter suitable for operation from a photovoltaic array with or without a battery for energy storage was also developed in this effort. A much needed intermediate power level 50-kW three-phase power conditioner, Sunverter Model 759-4-200, was the third product to evolve from the research and development. All designs take advantage of the ASIC and a complementary microprocessor sampleddata control system.

The ASIC-controlled power conditioners provide the high reliability, high efficiency, and low cost needed for photovoltaic applications. They cover the power range from the residential level to utility-sized installations.
\end{abstract}


Abacus Controls, Inc. Model 753-4-200 sunverter $\otimes$

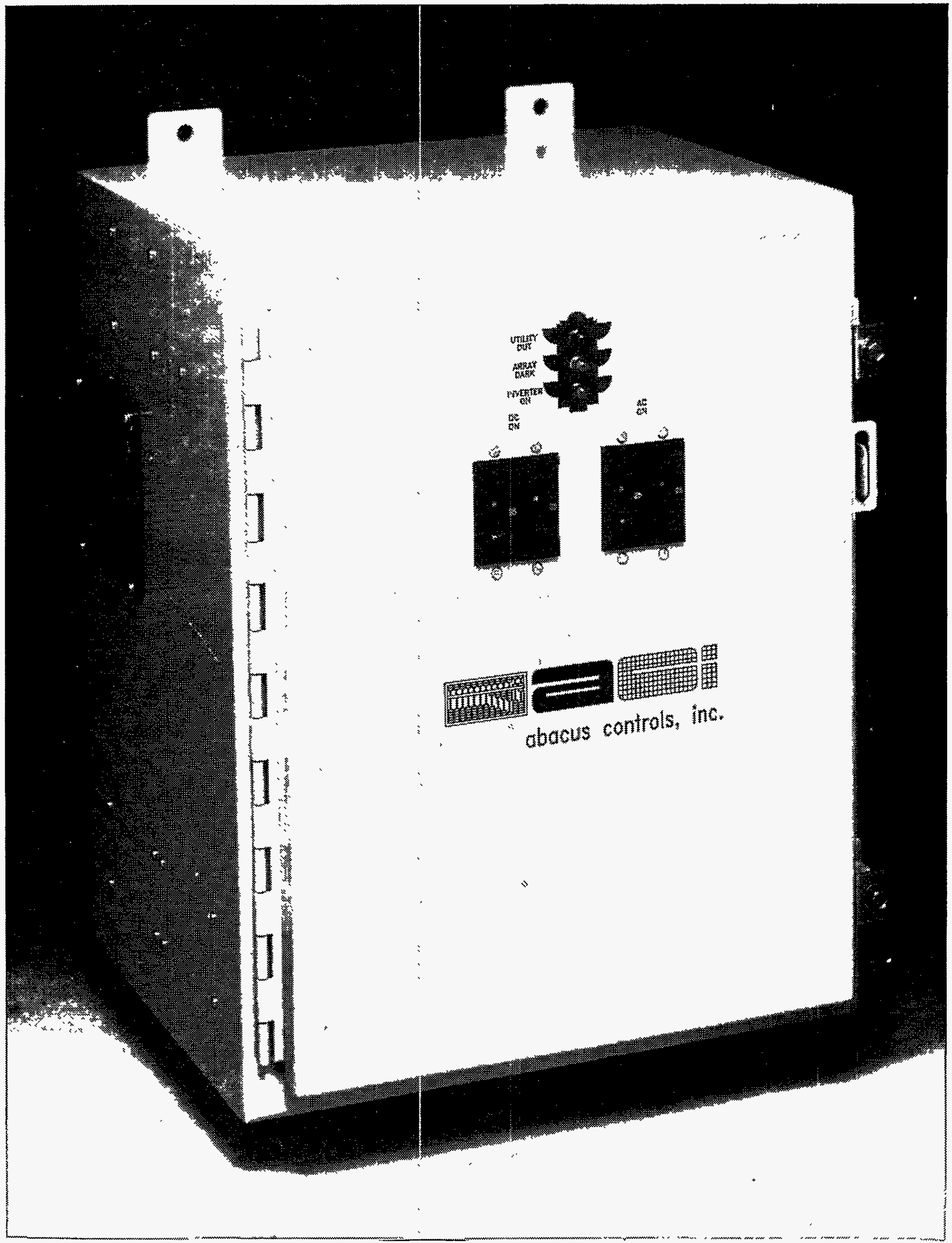




\section{TABLE OF CONTENTS}

1. INTRODUCTION 1

2. PHASE I REPORT BUMMARY 4

3. PROJECT OBJECTIVES 5

4. WORR DESCRIPTION 5

4.1 RESIDENTIAL UTILITY INTERTIE 5

4.2 RESIDENTIAI STAND ALONE INVERTER 6

4.3 50-KT THREE-PHASE UTILITY INTERTIE 6

5. SAFETY AND QUALITY FEATURES 10

5.1 SAFETY 10

5.2 LOSS OF UTILITY 13

5.3 POWER QUALITY 15

6. THE POWER RECYCLER, A SPINOFF APPLICATION 16 OF ASIC INVERTER TECHNOLOGY

$\begin{array}{llllll}6.1 & 0 & P & 8 & \text { TESTING } & 17\end{array}$

$\begin{array}{llr}6.2 & \text { BATTERY TESTING } & 19\end{array}$

7. CONCLUSION 20

$\begin{array}{ll}\text { REFERENCES } & 20\end{array}$

$\begin{array}{ll}\text { APPENDIX A } & 21\end{array}$ 


\section{INTRODUCTION}

Abacus controls Inc was awarded Phase II of the Small Business Innovation Research Grant No. DE-FG05-90ER80869 on February 5, 1991, after successfully completing Phase I in December 1990. The photovoltaic research program called for the modernization of the design of power conditioners by incorporating an ASIC and a complementary microprocessor into the controller to improve reliability and power quality, and to reduce the cost of power conditioners.

All of the technical and cost objectives set for the project, which was titled, "Application specific Integrated circuit to Improve Reliability and Power Quality and to Reduce Cost of PCs Control," have been met or exceeded. A full line of products, Sunverter ${ }^{\circledR}$, was designed and offered for sale. Detailed specifications appear in Appendix A.

To date, nineteen Model 753 series 5-kW Sunverters have been built, with four for export; and, three Model 759 series 50-kW sunverters have been built, one for export to a customer where strong foreign competition had to be overcome.

A value and performance comparison of the Abacus Controls sunverter, as it was prior to the $U S$ Department of Energy Small Business Innovative Research Grant, and as it has evolved as a result of the grant appears below. The selling price for the old unit, $\$ 10,800$, is in 1983 dollars while the new Sunverter price of $\$ 4290$ is in 1993 dollars and represents the current market price. The cost reduction is in both material and labor, with the labor reduction being most significant; test time during construction at the factory is reduced from five days to four hours.

\section{abacus controls inc Value and Performance Comparison}

\begin{tabular}{lll}
\hline item & '83 4-kW Sunverter & '92 5-kW Sunverter \\
\hline Selling Price & $\$ 10,800$. & $\$ 4290$. \\
Dimensions & $33 " \mathrm{H} \times 26 " W \times 15.5 " \mathrm{D}$ & $20 " \mathrm{H} \times 16 " W \times 14 " \mathrm{D}$ \\
Volume & $13300 \mathrm{cu}$ in & $4500 \mathrm{cu}$ in \\
No. of parts & $1019 \mathrm{total}$ & $236 \mathrm{total}$ \\
Adjustments & 16 pots & 0 pots \\
Speed of Response & 50 milliseconds & 0.5 milliseconds
\end{tabular}


The reductions in dimensions and volume were not a goal in themselves but resulted from other design improvements. The final design retains a $60 \mathrm{~Hz}(50 \mathrm{~Hz}$ for export models) isolation transformer to meet the National Electrical Code requirements for simultaneous grounding at both the array and utility interfaces.

Incorporation of an application-specific integrated circuit (ASIC) and a complementary microprocessor into the controller design has the desirable effect of reducing the parts count from 1019 electrical components to 236 and the number of control cards from eleven to one as illustrated below. The elimination of all sixteen adjustments from the prior design also contributes to the increase in reliability.

Power quality is enhanced by the hundred-to-one improvement in the speed of response from $50 \mathrm{milliseconds}$ to $0.5 \mathrm{milliseconds.} \mathrm{A}$ sampled data control system examines the current waveshape into the utility line 96 times per cycle. The faster speed of response also plays a significant role in reliability improvement since reaction time to surges, dips and other utility disturbances is quick enough to ride through without component overstresses.

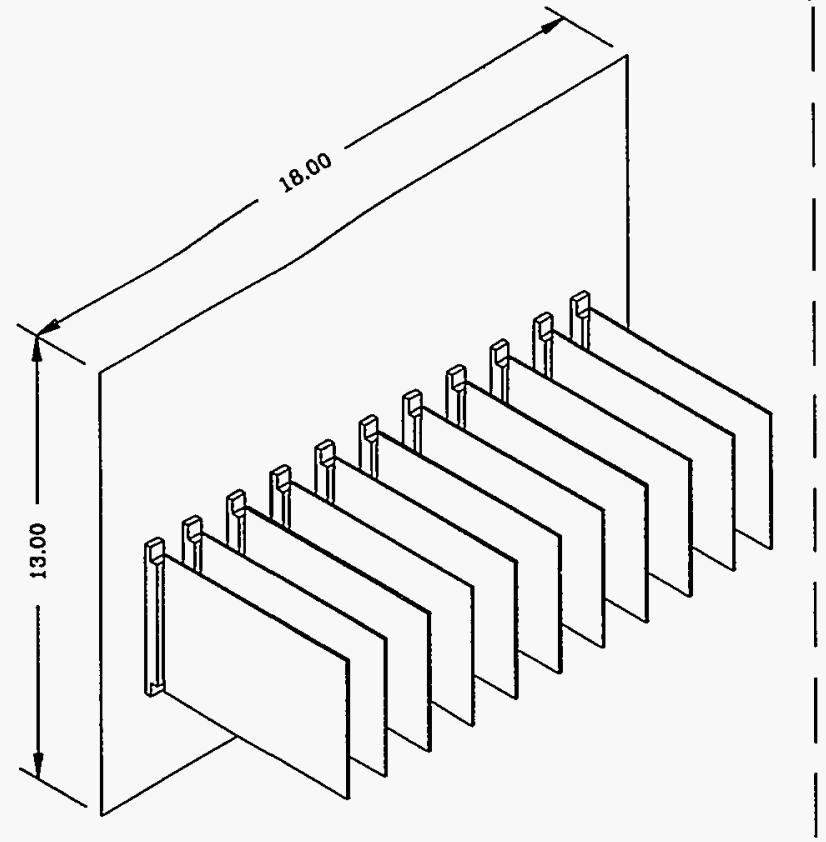

'83 4KW SUNVERTER

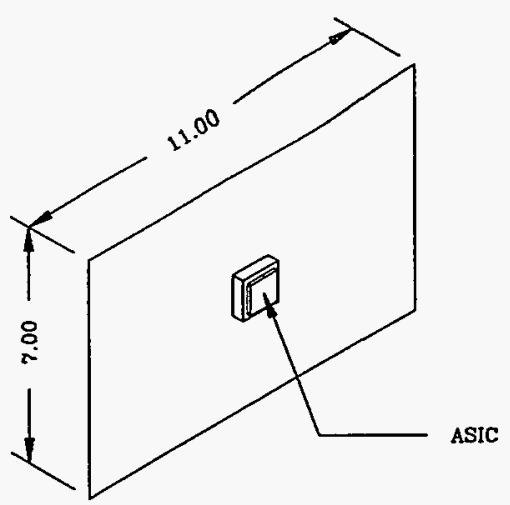

'92 5KW SUNVERTER 
This report contains background information on the Phase I effort and the project objectives, a description of work, and the safety and quality features of the sunverter design.

The Sunverter converts dc power to ac power with the ac power being applied to the utility grid. Since the inverter is a cogenerator of electricity, with the utility as the primary source, special safety and power quality requirements are imposed that do not normally apply to inverters. Of primary concern is the safety of utility linemen; when the utility loses power, all cogenerators must turn off automatically within one second. other safety features are described in detail.

The sunverter serves as a constant ac current source to the utility grid. Because the system is a cogenerator, it is imperative that the power supplied to the utility grid be low in total harmonic distortion (THD) and near unity power factor. A second power quality consideration is the THD in the current from the dc source, a characteristic common to all inverters but especially critical to the sunverter because of its impact on the dynamic operating point of the photovoltaic array.

The products developed under this grant are directly applicable to energy sources other than photovoltaics, such as wind generators and fuel cells. Two models have been sold for fuel cell applications to a customer in British Columbia, Canada, and this emerging market shows promise for expansion in the latter half of this decade.

The technology to convert dc power to ac power and cogenerate with the utility has been largely mastered and a product that is both cost effective and reliable has resulted from the SBIR grant. An immediate application for this broader product concept is to replace the wasted heat produced in testing dc power supplies and discharging batteries with power recycled to the utility grid, thus conserving power for needed uses. The new technology is reported below. 


\section{PHASE I REPORT SUMMARY}

Power conditioners currently in use in photovoltaic cogeneration installations do not use large-scale integration technology. It was the objective in phase I to research the feasibility of improving the accuracy, speed of response, and the reliability of a power conditioner by utilizing a commercially available ASIC, and this objective has been successfully met.

The research began with the clerivation of the control equations for the proposed sampled data control system that delivers ac current to the utility line and operates the photovoltaic array at its maximum power point. A design was implemented using an ASIC and a microprocessor to take advantage of both large-scale integration technologies. The power conditioner has a proven accuracy of better than $1 \%$ and a speed of response faster than 400 microseconds. This translates into a computer-controlled performance without all known shortcomings that have limited the performance of previous power conditioners.

Fundamental to the productivity of power conditioners is the minimization of parts. Compared to a product delivered in 1988, the system electrical parts count has been reduced from 1019 to 236 components. All sixteen adjustments from the old design have also been eliminated. The required operating points are programmed into the microprocessor PROM. No adjustments means minimum test time.

The mechanical design of the controller takes full advantage of the parts reduction. A single printed circuit card 7" $x$ 8.3" $x 1^{\prime \prime}$ replaces a backplane board that had eleven plug-in cards that occupied a volume of 18" $x$ 13" $x$ 8". The newly designed 5-kw residential sunverter will be housed in a standard NEMA wallmounted cabinet that is $20^{\prime \prime h} \times 16^{\prime \prime} \mathrm{W} \times 14^{\prime \prime} \mathrm{d}$ and weighs $160 \mathrm{lbs}$.

Favorable simulation results are supported with projected computer graphics both for the current being returned to the utility and for the maximum power tracker. In both cases, the cost advantage of making design improvements during simulations rather than with products during test is demonstrated.

Several cost reduction factors, both material and labor, are possible. For the $5-\mathrm{kW}$ residential design, the small quantity unit price is $\$ 4290$, or $\$ 0.86$ dollars per watt, under the 1985 target of one dollar per watt.

The advantages of applying large-scale integration technology to photovoltaic cogeneration installations and the feasibility of producing these power conditioners are now established. Manufacturing costs will be significantly reduced with the ASIC and microprocessor-implemented controller. 


\section{PROJECT OBJECTIVES}

There were four major technical objectives for the Phase II program, and each of these was divided into definable and measurable tasks. The technical objectives were

1. Complete the design optimization of a 5-kw line-tied power conditioner, Model 753-4-200 Sunverter, that was the principal beneficiary of the Phase I effort. Research is required into the best available power output semiconductor with consideration given to performance and cost projection. Three units with competing power output stages will be built and tested.

2. Research the feasibility of a 5-kW stand-alone inverter. The combination of ASIC and microprocessor large-scale integration technology should prove as applicable to a standalone inverter as it is to a line-tied inverter. The mechanical design should be identical to its sunverter counterpart. A prototype will be built and tested.

3. Perform the research and development for a 50-kw threephase utility line-tied power conditioner. Define the requirements for an ASIC and a microprocessor and select the optimum combination of components for the three-phase controller. Design a power bridge. Develop manufacturing hardware and software, and manufacture and test a prototype 50-kw power conditioner.

4. With the 50-kW power conditioner as a building block, research and design a central controller unit that can manage from two to ten power conditioners with powers up to $500 \mathrm{~kW}$ in a utility application. Build and test a prototype system.

\section{WORK DESCRIPTION}

The work was organized and managed under the four tasks above.

\subsection{RESIDENTIAL UTILITY INTERTIE}

For the residential power conditioning unit, the Model 753-4-200 Sunverter was completely designed, manufactured and tested. The prototype built under the grant was tested at Abacus controls with an Abacus Controls Solar Array Simulator, Model SASI, to prove the performance capability and to demonstrate the product's reliability.

The prototype was delivered to the Florida Solar Energy Center for field testing in April 1992. Preliminary test results were reported in June 1992.1 
Nineteen additional Sunverters have been manufactured or are being processed to individual customer purchase order requirements. Economic feasibility has been proven as has reliable performance. ${ }^{2}$

Figure 1 is the Sunverter simplified diagram. The solar array delivers direct current to the sunverter bridge, which converts the dc to ac and delivers it to the utility. A capacitor filters the current drawn by the Sunverter bridge, minimizing solar array ripple voltage. An inductor filters the pulse width modulated output voltage of the sunverter bridge to a level that minimizes the inverter output current total harmonic distortion.

The Sunverter bridge has four Insulated Gate Bipolar Transistors (IGBTs) arranged in an "H" bridge with an isolation transformer connected across the center of the bridge. The IGBT is superior to the older bipolar transistor in speed of response, safe operating voltage capability, efficiency, simplified snubber and clamp circuits. Also, it offers a two orders of magnitude reduction in driver circuit power requirements. These features also reduce the cost of supporting parts.

The digital controller in Figure 1 senses both input and output voltages and currents. Through a complex multiloop control strategy, it provides on/off instructions to the IGBT's. Accomplishing all control functions through a single power stage maximizes reliability, maintainability and efficiency and minimizes cost, size and weight.

\subsection{RESIDENTIAI STAND ALONE INVERTER}

A 5-kW Model 453-4-200 stand-alone inverter was designed and built using the same microprocessor and ASIC controller as in the residential utility intertied inverter. The first unit was designed, manufactured and thoroughly tested with both the SASI and battery inputs. Pricing will be the same as the utility intertied inverter.

The package for the stand-alone inverter is also the same as for the utility intertied. This provides maximum interchangeability of parts for quantity purchases, thus reducing costs and inventories for both products.

\subsection{0-kW THREE-PHASE OTILITY INTERTIE}

After an extensive evaluation program, it was decided that the optimum three-phase design for the utility intertie is three individual current source inverters, one tied to each of the utility phases. The simplicity of the single-phase design was established with the residential $5-\mathrm{kW}$ design. All of the threephase designs that were evaluated were three times as complicated as the single-phase design because of the current source concept chosen. With three independent modules in a three-phase system, no 


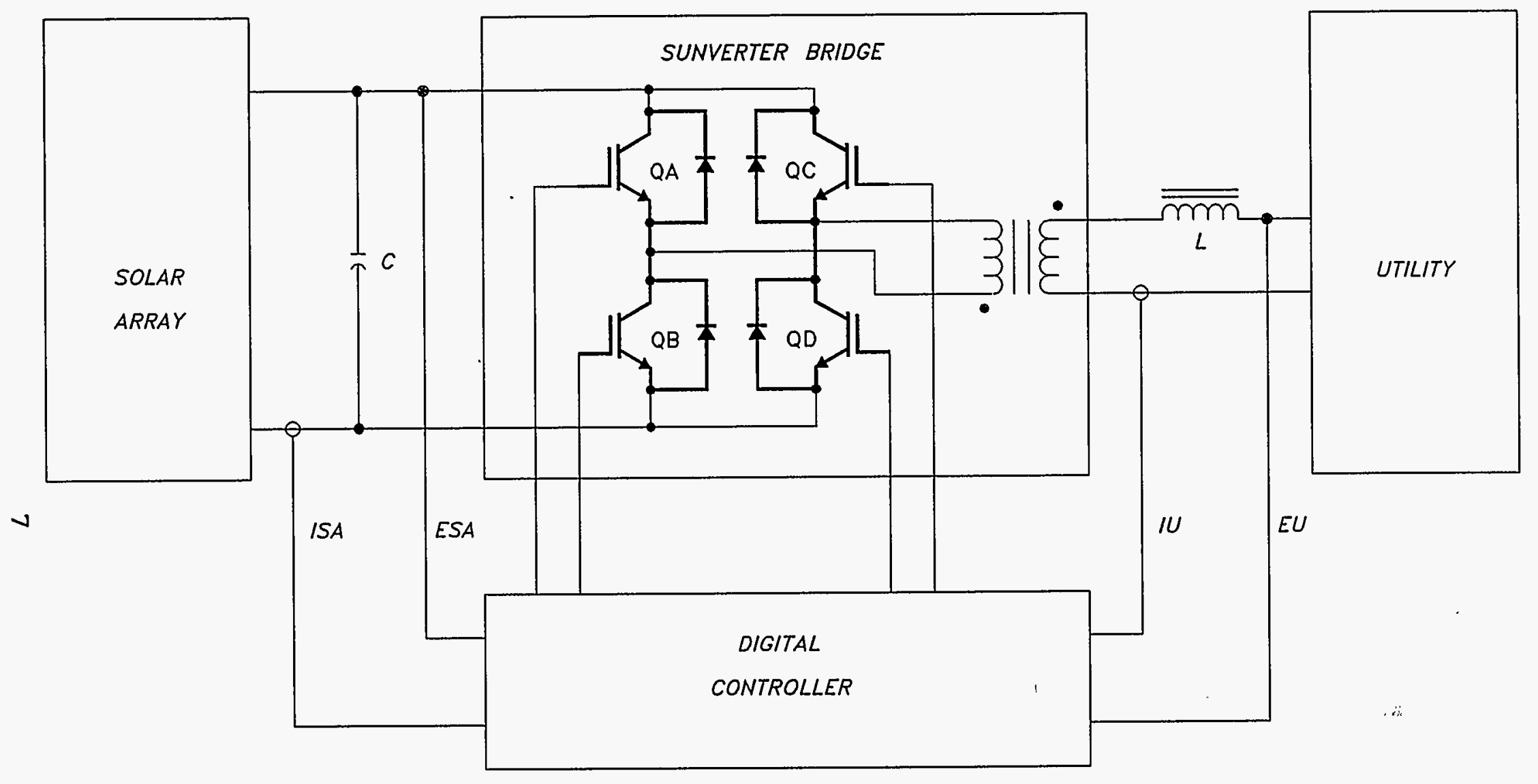

NOMENCLATURE:

ESA - SOLAR ARRAY VOLTAGE

ISA - SOLAR ARRAY CURRENT

EU - UTILITY VOLTAGE

IU - UTILITY CURRENT

FIGURE 1 SUNVERTER SIMPLIFIED DIAGRAM 


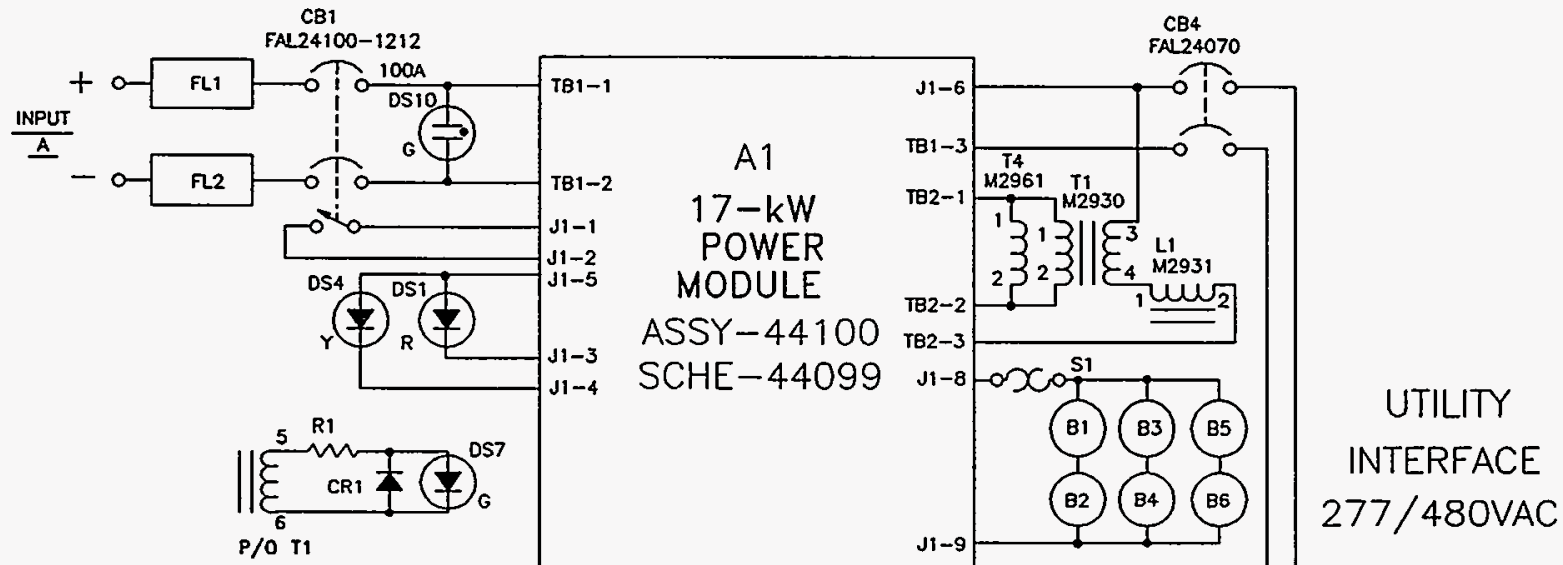

SOLAR ARRAY

160-240V
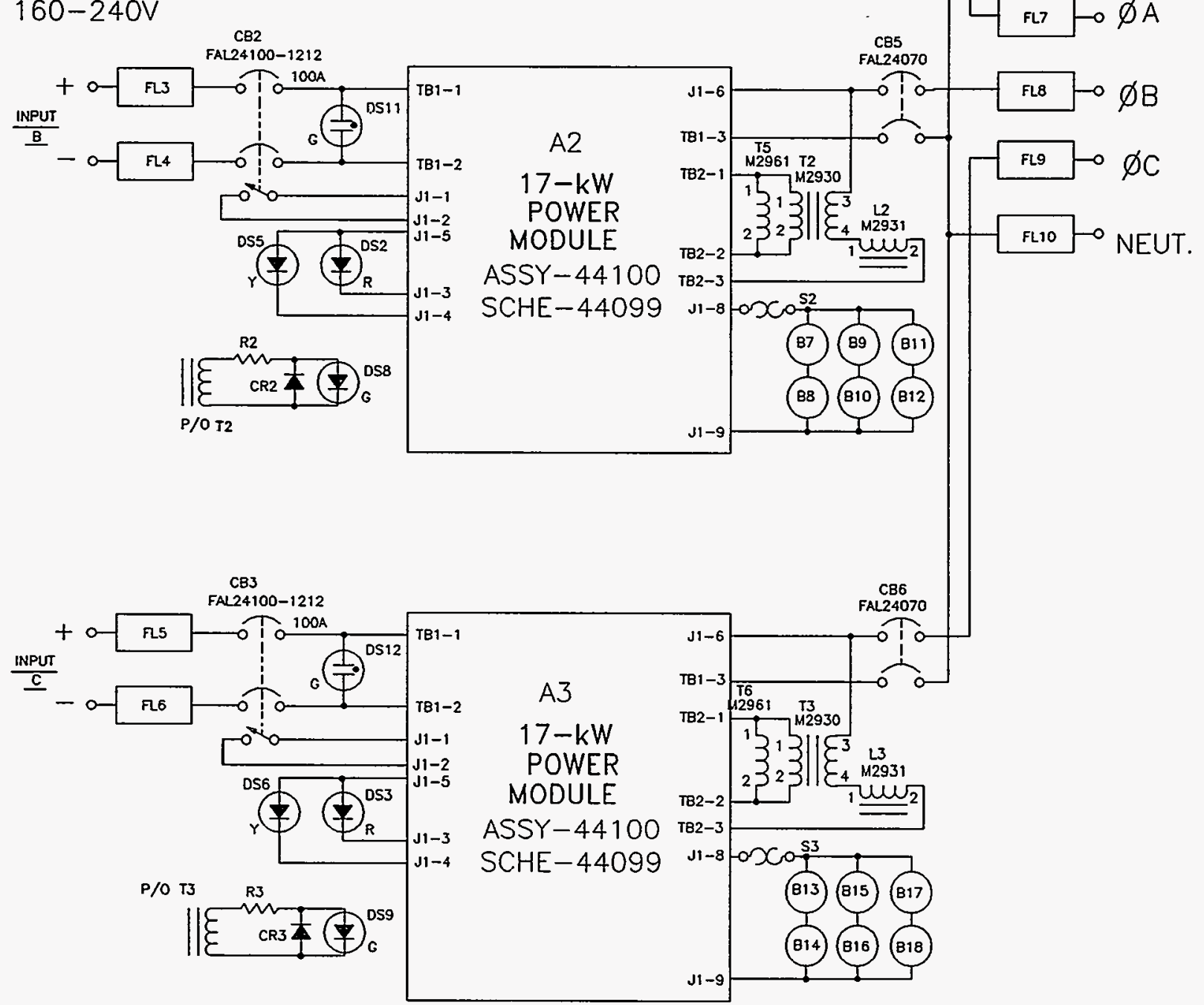

FIGURE 2

50-kW SUNVERTER MODEL 759-4-200 
single failure can interrupt the operation of more than one phase, and even with a failure, two thirds of the power is delivered to the utility grid.

A prototype 50-kW Sunverter was built as part of the DOE SBIR Grant, and a second unit was built and delivered to a utility. The schematic diagram for the 50-kW Sunverter Model 759-4-200 appears in Figure 2. The solar array is divided into three sections, one for each phase, and these are delivered to the three single-phase 17-kW Power Modules A1 through A3 for phases A, B and C respectively, through dc RFI line filters.

Each power module is phaselocked to its designated line phase and equipped with its own single-phase output isolation transformer. Each section of the array is operated at its maximum power point by the microcontroller in each power module.

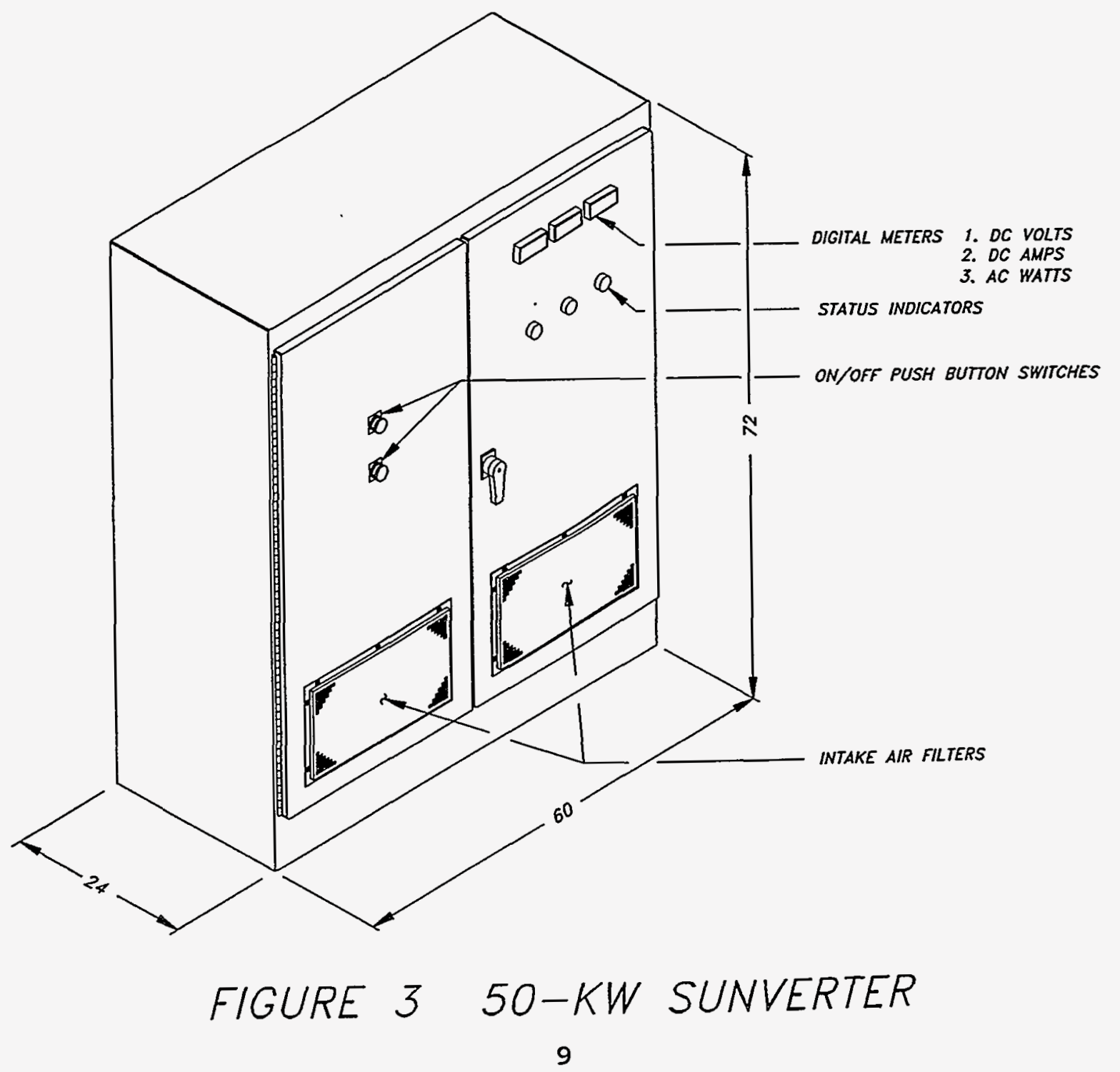


Operation of individual power modules is the same as that described above for the 5-kW Sunverter Model 753-4-200.

A single NEMA 12 enclosure houses the 50-kW three-phase sunverter and provides safety, ventilation, doors equipped with RFI gaskets and interlocks, and removable eye bolts for easy transportation. A heavy wooden crate is palletized for safe trucking and moving about. As shown in Figure 3, the NEMA 12 cabinet has meters, switches and indicators (not shown) mounted on the front doors. only 24" depth is required; all servicing, testing, and repairs can be made from the front.

All major components are shown in the photograph on the following page. Three single-phase transformers, the only heavy components, are shown mounted to the base plate. This keeps the CG of the cabinet in the lower third of the vertical plane and in the center of the horizontal plane. The transformers have built-in leakage inductance and represent less weight and cost than a three-phase transformer and three inductors.

The three interchangeable power modules are mounted on the top and are easily removed and replaced as a total assembly including the associated sunverter PC board or as individual IGBT and driver PC card modules. Other major components are located on the center deck.

\section{SAFETY AND QUALITY FEATURES}

Normally an inverter converts dc power to ac power and delivers the ac power to a dedicated load. The sunverter converts dc power to ac power and delivers the ac power to the utility grid. The Sunverter is connected to two power sources, one dc and one AC. With two power sources, special safety precautions are necessary to protect personnel from shock hazards.

Quality of the inverter output power is critical because the power is being injected into the utility grid. Any noise or interference created by the inverter will be imposed on other loads within the user facility and possibly on other utility customers. Filters within the sunverter prevent problems being promulgated onto the utility grid.

\subsection{SAFETY}

Personnel safety is of primary concern, and two potential hazards must be guarded against in the design of the sunverter. The first concern is for the utility company lineman: since the sunverter is a cogenerator, it is imperative that it disconnect from the utility line whenever the utility power is unavailable. 
Abacus Controls, Inc. Hodel 759-4-200 $50 \mathrm{~km}$, sunverter $\otimes$

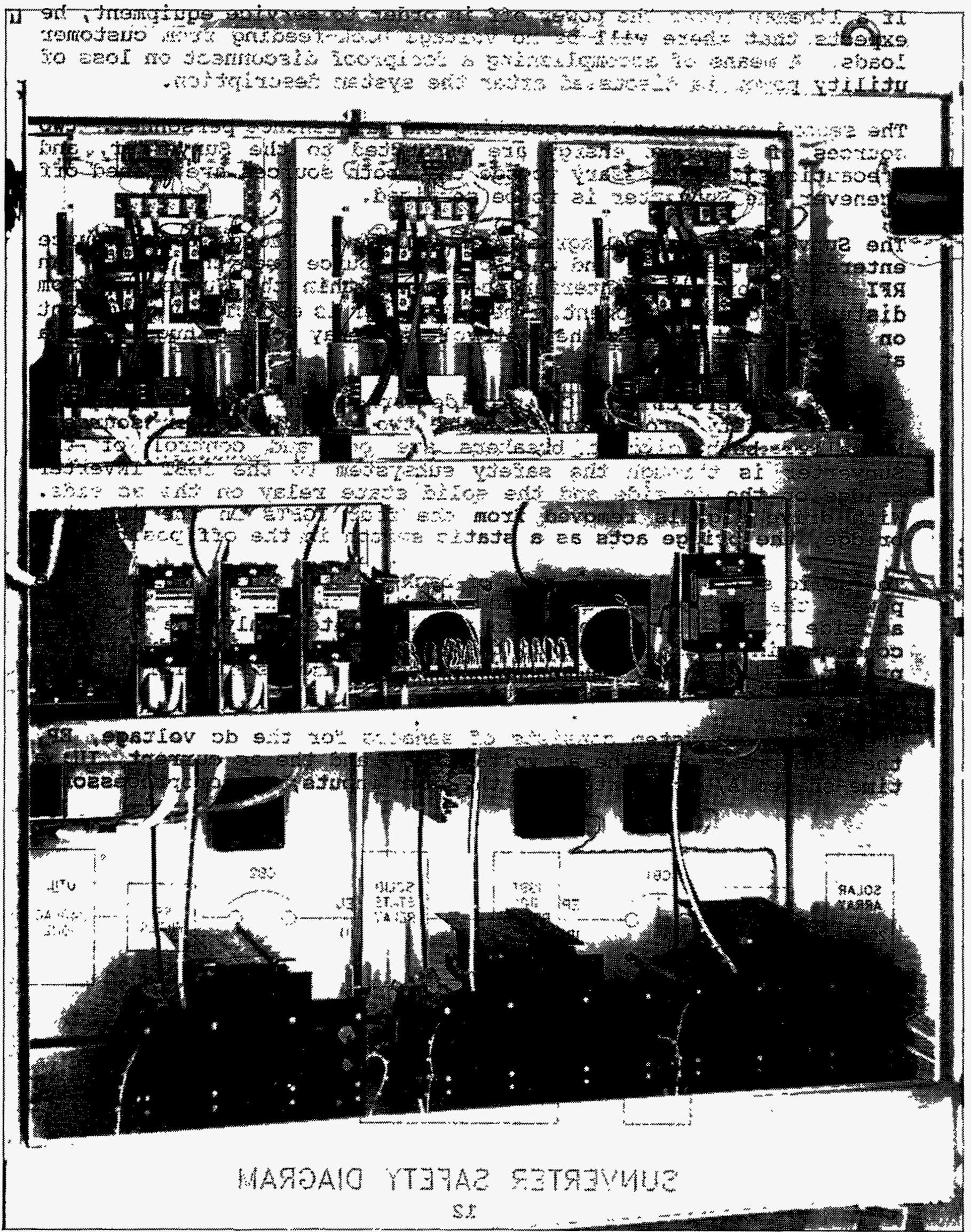


If a lineman turns the power off in order to service equipment, he expects that there will be no voltage back-feeding from customer loads. A means of accomplishing a foolproof disconnect on loss of utility power is discussed after the system description.

The second concern is for operating and maintenance personnel: two sources of electric energy are connected to the sunverter, and precautions are necessary to see that both sources are turned off whenever the sunverter is to be serviced.

The Sunverter Safety Diagram appears below. The dc power source enters from the left, and the ac power source from the right. An RFI filter prevents interference from within the sunverter from disturbing other equipment. The RFI filter is especially important on the dc input because the photovoltaic array forms a huge antenna at radio frequencies.

Circuit breakers $\mathrm{CB} 1$ and $\mathrm{CB} 2$ provide turn-on and turn-off means as well as safety protection for the two electric power sources. Normally, both circuit breakers are on, and control of the Sunverter is through the safety subsystem to the IGBT INVerter bridge on the dc side and the solid state relay on the ac side. With drive signals removed from the four IGBTs in the inverter bridge, the bridge acts as a static switch in the off position.

The solid state relay is a pair of back-to-back SCRs. Without gate power, the SCRs become a static switch in the off position on the ac side of the Sunverter. In the on state, only the SCR that conducts inverter current to the utility is gated on during the proper utility half cycle; this makes it impossible for utility power to flow into the sunverter.

The safety subsystem consists of sensors for the dc voltage, EP, the dc current, IP, the ac voltage, EU, and the ac current, IU; a time-shared $A / D$ converter for the four inputs; a microprocessor;

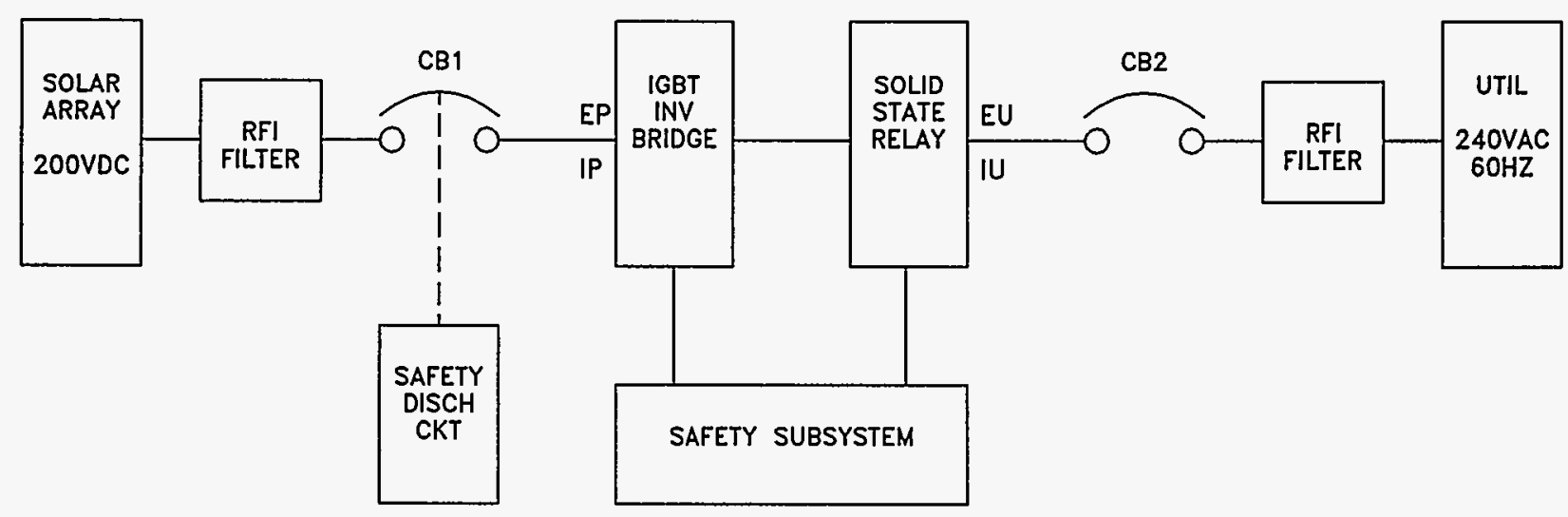

SUNVERTER SAFETY DIAGRAM 


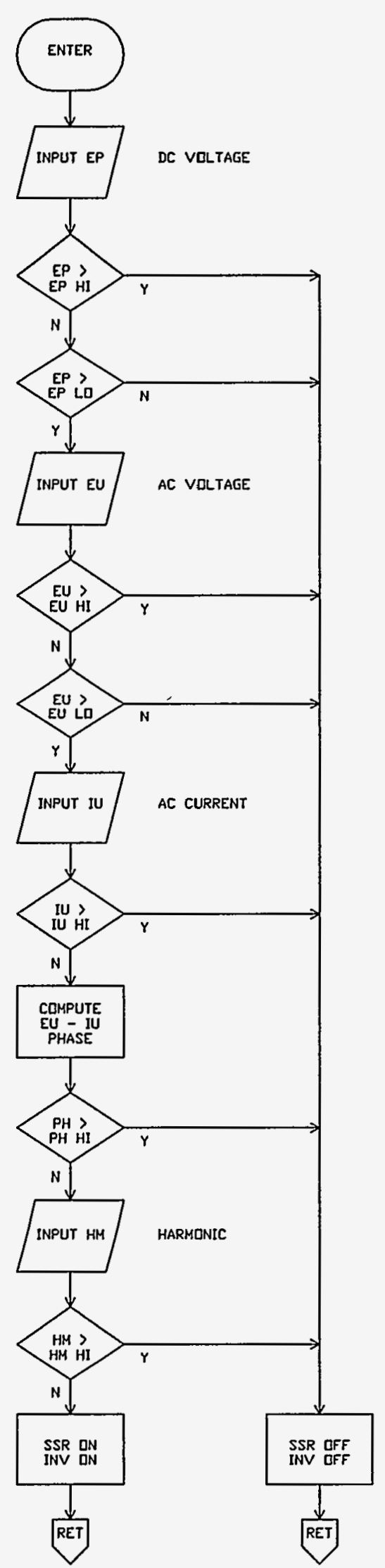

FLDW CHART SAFETY SUBSYSTEM and, two outputs for on-off control, one to the IGBT INVerter bridge and one to the solid state relay.

The flow chart for the safety subsystem is on the left. This routine, which shares the microprocessor with sunverter control functions, is performed eight times per cycle of the 60-Hz utility frequency. Thus the repetition rate is approximately every two milliseconds.

As indicated in the flow chart, the dc voltage is tested first to be within tolerance (less than the EP HI limit and greater than the EP LO limit). The same test is applied to the ac voltage. AC current is tested for being less than the IU HI limit, followed by an out-of-phase computation that tests to see that the upper limit for the phaselock loop has not been reached.

The final test is for the harmonic ripple in the output ac voltage. This is the measurement that protects against loss of utility power, and it is explained below.

\subsection{LOSS OF UTILITY}

A critical safety issue for a cogenerator is to disconnect from the utility line when the utility line loses power. There can be no unexpected sources of power that might confront utility linemen performing maintenance functions.

Normally when the utility turns off the controlled-current ac output of the Sunverter times the impedance of the utility line results in an ac voltage out of tolerance; as elaborated above, the ac voltage is tested approximately every two milliseconds by the safety subsystem. An open-circuit utility results in a EU HI rejection, and a short circuit or near short circuit results in a EU LO rejection.

There is an improbable but possible condition for which protection is imperative: 
the resistance of the load remaining on the utility line times the controlled current from the inverter falls inside the tolerance range for the utility voltage. Unless a separate turn-off mechanism were provided, the cogenerating sunverter would remain on line as long as the utility voltage tests within the safety subsystem limits EU HI and EU LO.

The condition of a cogenerator remaining on when the utility power source is off is popularly called "islanding" by utility personnel.

The separate turn-off mechanism in the sunverter is to sense the harmonic voltage on the utility line at the switching frequency of the Sunverter and turn off when the harmonic voltage exceeds a safe limit. With the utility present, the source impedance of the utility line is very low compared to the impedance of the inverter in the Sunverter. Under this condition, the harmonic voltage is low.

When the utility is absent, the impedance of the utility line is the load that remains, and this is necessarily significant compared to the impedance of the Sunverter. The harmonic voltage (HM in the flow chart safety system) exceeds the upper limit HM HI and the Sunverter correctly disconnects from the utility line.

The oscilloscope tracing below shows the utility voltage at the beginning and the inverter voltage only after the utility was turned off. The utility voltage was $240 \mathrm{VAC}$, and the remaining resistor on the utility line was selected so that the "islanding" voltage was also 240VAC. Turn-off occurred in less than one cycle or approximately 12 milliseconds.

\section{UTILITY LOSS / HARMONIC DISCONNECT}

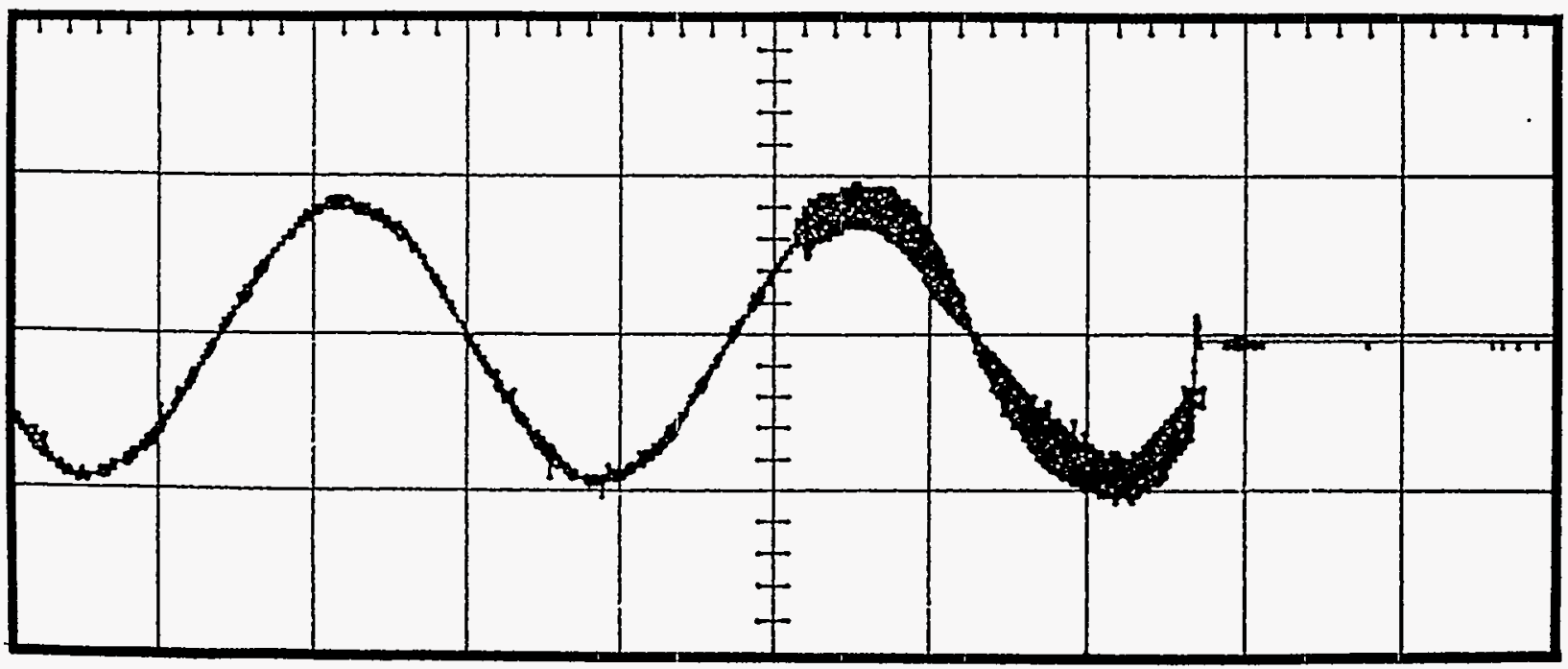




\subsection{POWER QUALITY .}

The Sunverter injects power into the utility grid as a controlled current. The THD and power factor of the inverter current are the measures of power quality. The sunverter has a digitally stored sinewave as reference and a sampled-data control system that computes the desired output current each sampling period. The significant harmonics in the sampled-data output are at the sampling frequency minus the utility frequency and the sampling frequency plus the utility frequency. ${ }^{3}$

An oscilloscope trace of the current into the utility grid is shown below. The switching frequency, $5760 \mathrm{~Hz}$, is clearly visible. In this example, the THD of the current was measured at $3 \%$. The only filtering required between the pulsewidth switching of the IGBT inverter bridge and the utility is a linear inductor.

The standards for harmonics for both public utilities and cogenerators are specified in terms of voltage, with the maximum for an individual harmonic set at $3.0 \%$ and the THD set at $5.0 \%{ }^{4}$ However, cogenerators that are insignificant in power capacity compared to the utility will have standards in the future that will set limits on injected current harmonics.

INVERTER CURRENT

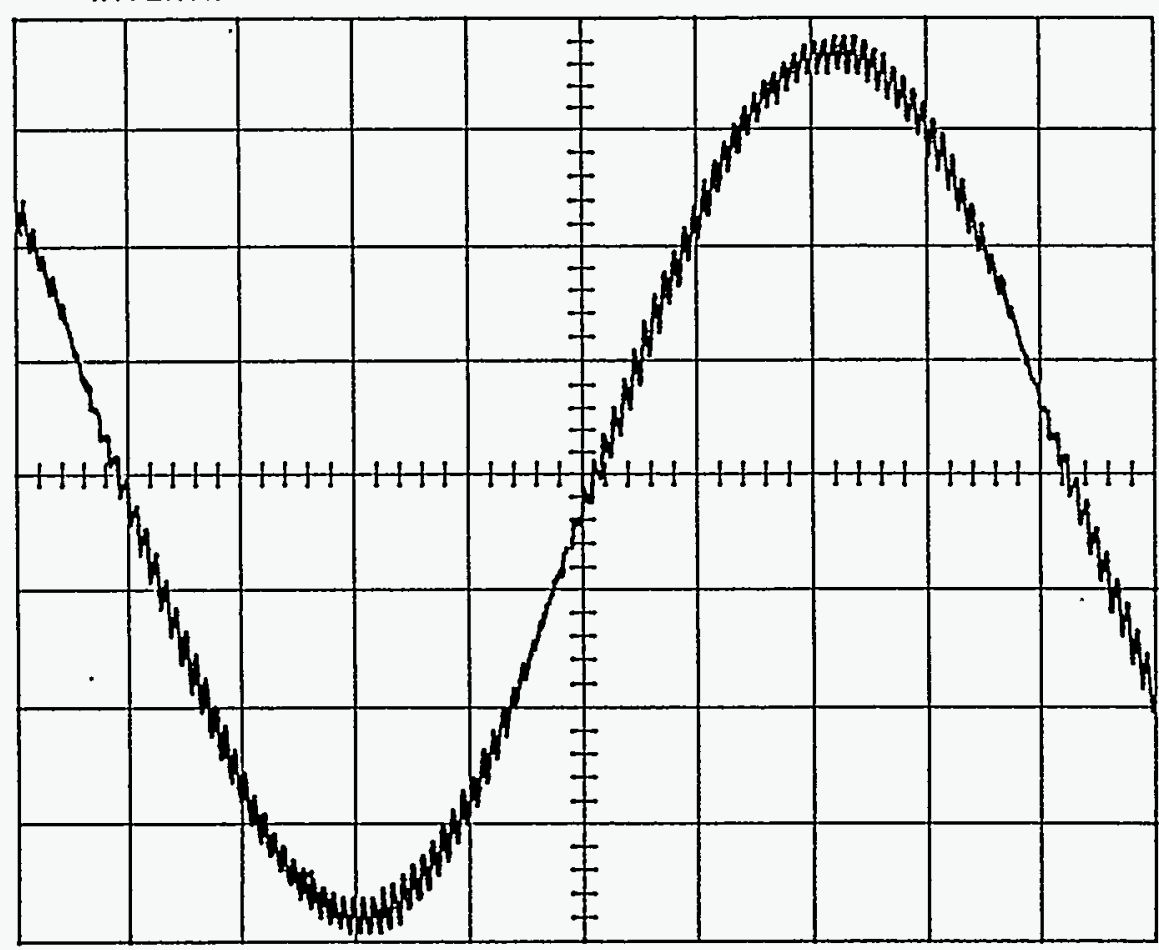

FREQUENCY $60 \mathrm{HZ}$

10 A PER DIV 
The power factor of the inverter current is maintained at .99 or better by a phaselock loop that is independent of the sampled-data control loop for the inverter current amplitude. since the phaselock loop contains a voltage controlled oscillator (VCO), there is a natural integration between frequency and phase that drives the phase error to zero.

\section{THE POWER RECYCLER ${ }^{\circ}$, A SPINOFF APPLICATION OF ASIC INVERTER TECHNOLOGY}

The conventional method for testing power supplies, batteries, fuel cells and other sources of electric power is with resistors for load simulation. The end result is wasted heat, and the cost of the wasted heat is increased when the heat is removed by air conditioners. The Power Recycler converts dc power to ac power and recycles the power to the utility grid. The recycled electric energy is delivered to useful loads, including the input of the power supplies under test.

In addition to the ecological benefits of power conservation and perhaps even peak power shaving, the economics of power recycling is very favorable. For example, the savings from the utility bill can pay the cost of an installation in less than a year; after the initial costs are amortized, the reduced utility bill results in continuing savings.

The estimates of the amount of electric energy wasted in the United states and other technologically advanced nations in the testing of power sources runs into the hundred millions of kilowatt hours annually. The power sources range from small ac to dc power supplies for the home entertainment and personal computer industries to large battery installations used for peak power shaving by electric utilities. Uninterruptible power supplies (UPS) with both ac and dc output configurations are included.

The power recycling process is shown below for the dc power supply application. Since the popular voltages for computers, process controllers and other modern electronic equipment are relatively low, e.g., 5V, $12 \mathrm{~V}, 24 \mathrm{~V}$ or $48 \mathrm{~V}$, the dc power supplies are shown in the figure connected in series. It is desirable to take advantage of the high efficiency achievable with inverters at dc voltages at $120 \mathrm{~V} d c$ and above. Also, the most cost-effective inverters are at power ratings much higher than the dc power supplies whose power ratings are application specific for their intended use.

There is no harm or risk in connecting dc power supplies in series. The same dc current flows through all of the power supplies. There are three failure modes for the individual power supply, and the series connection tolerates each failure mode and protects the remaining power supplies. 
The digital controller, a sampled-data control system, contains both a microprocessor and an application-specific integrated circuit (ASIC). The microprocessor performs long-term control and safety functions with software while the ASIC makes microsecond decisions, such as power IGBT pulsewidths with hardware control. The two combine in a phaselock loop to maintain the inverter current to be perfectly in phase with the utility voltage; this results in the highly desirable unity power factor operating point, which corresponds to the maximum power transfer from the dc power supplies under test to the utility grid.

\subsection{U P 8 TESTING}

The UPSs that are produced in high quantity, especially those intended for the personal computer market, have full rated power battery storage times in the range 5 minutes to 20 minutes. To achieve low cost in testing while retaining high quality in product, it is necessary to run a full load battery discharge test. The batteries must be charged before the discharge test and again after the test so that the end user receives a UPS with a fully charged battery.

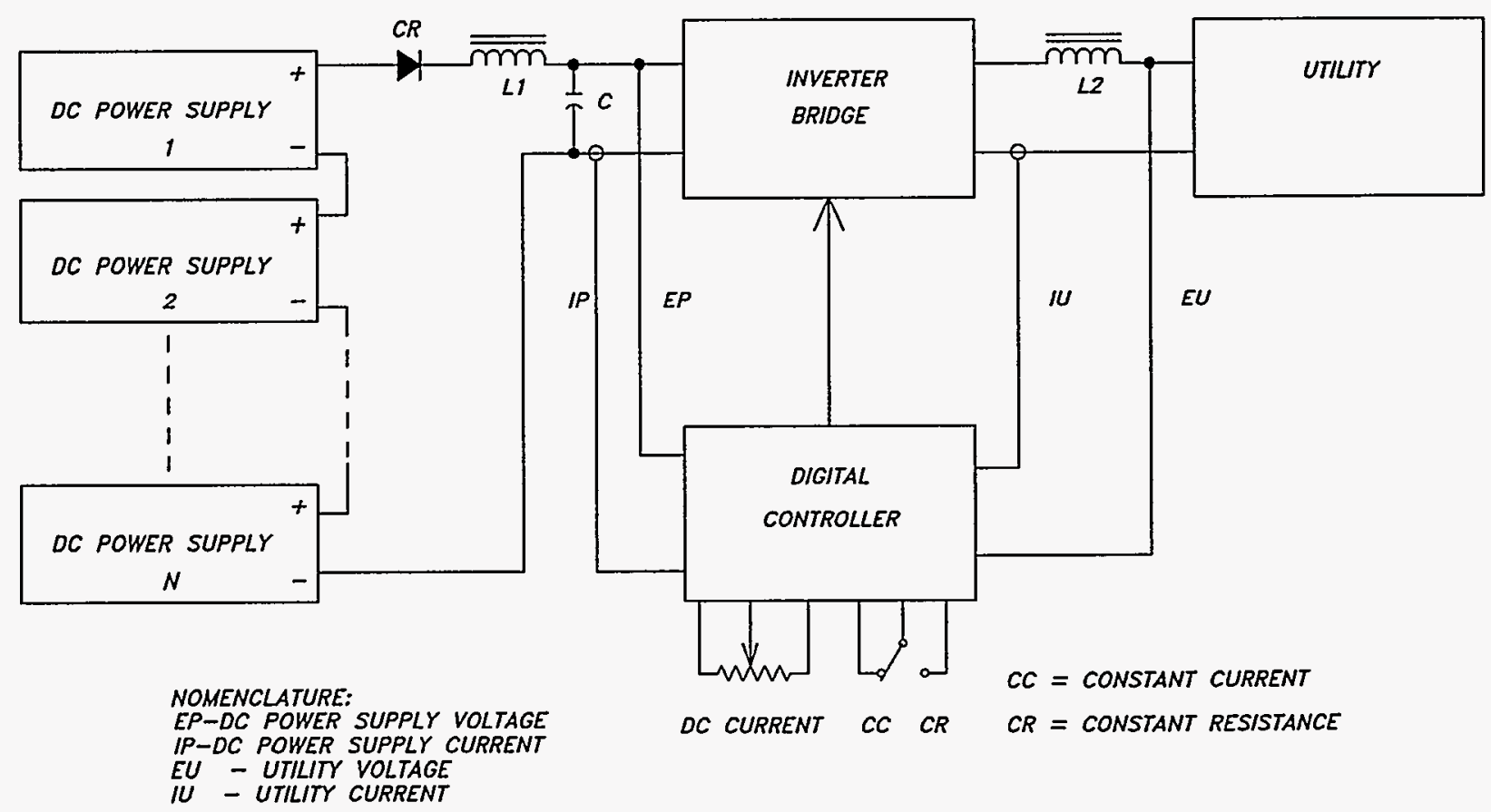

POWER RECYCLING 
The UPS test setup is shown below. Each UPS is equipped with its own line cord for the utility interface and a receptacle for the load interface.

Because rapid change-over from one product rating to another is an inherent requirement in efficient manufacturing, a special test fixture is used for each power rating.

The test fixture contains an isolation transformer, a rectifier bridge, and a filter capacitor for each UPS to be tested. With the power recycler connected across all of the UPS networks in series and operated in the constant current mode, the simulation of a typical personal computer load is nearly perfect. The output of the power recycler is connected to the utility in front of the switch or relay that sets all of the UPSs in either the charge condition (switch closed) or the discharge mode (switch open).

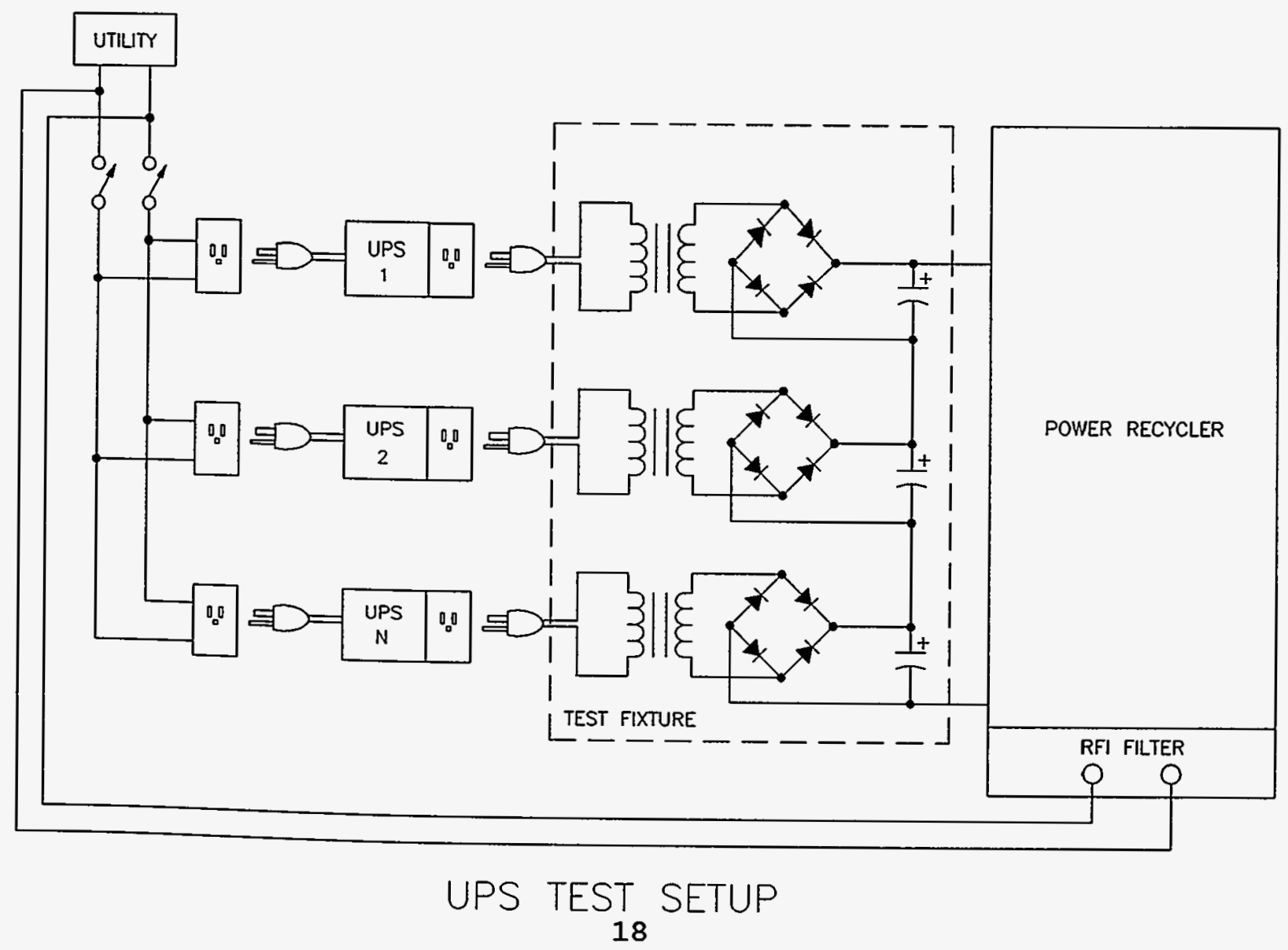




\subsection{BATTERY TESTING}

The power recycler is readily adaptable to service as a battery charger as well as a battery discharger. The advantages of "bimode" operation in UPS applications is described in the literature. 5 Battery charging and discharging applications have been demonstrated in renewable energy systems. ${ }^{\circ}$

The same power components, e.g., the four IGBTs in the bridge, the output transformer, etc., are used in both modes of the bimode power recycler, with a resultant cost saving and improvement in reliability. In the battery charger/discharger block diagram an external customer controlled relay sends a signal to the Digital controller to either charge the battery from the utility or to discharge the battery into the utility.

In the charge mode, the bridge charger applies a constant current to the battery until float charge is reached, at which point the charger applies a taper charge and finally a constant voltage charge at the float voltage. In the discharge mode, the power recycler is set in the constant current mode of operation.

Safety features include a minimum discharge voltage at which point the power recycler turns off; a separate minimum voltage from which discharging can commence; and, a safe upper limit voltage set slightly above the float charge voltage beyond which the power recycler will turn off.
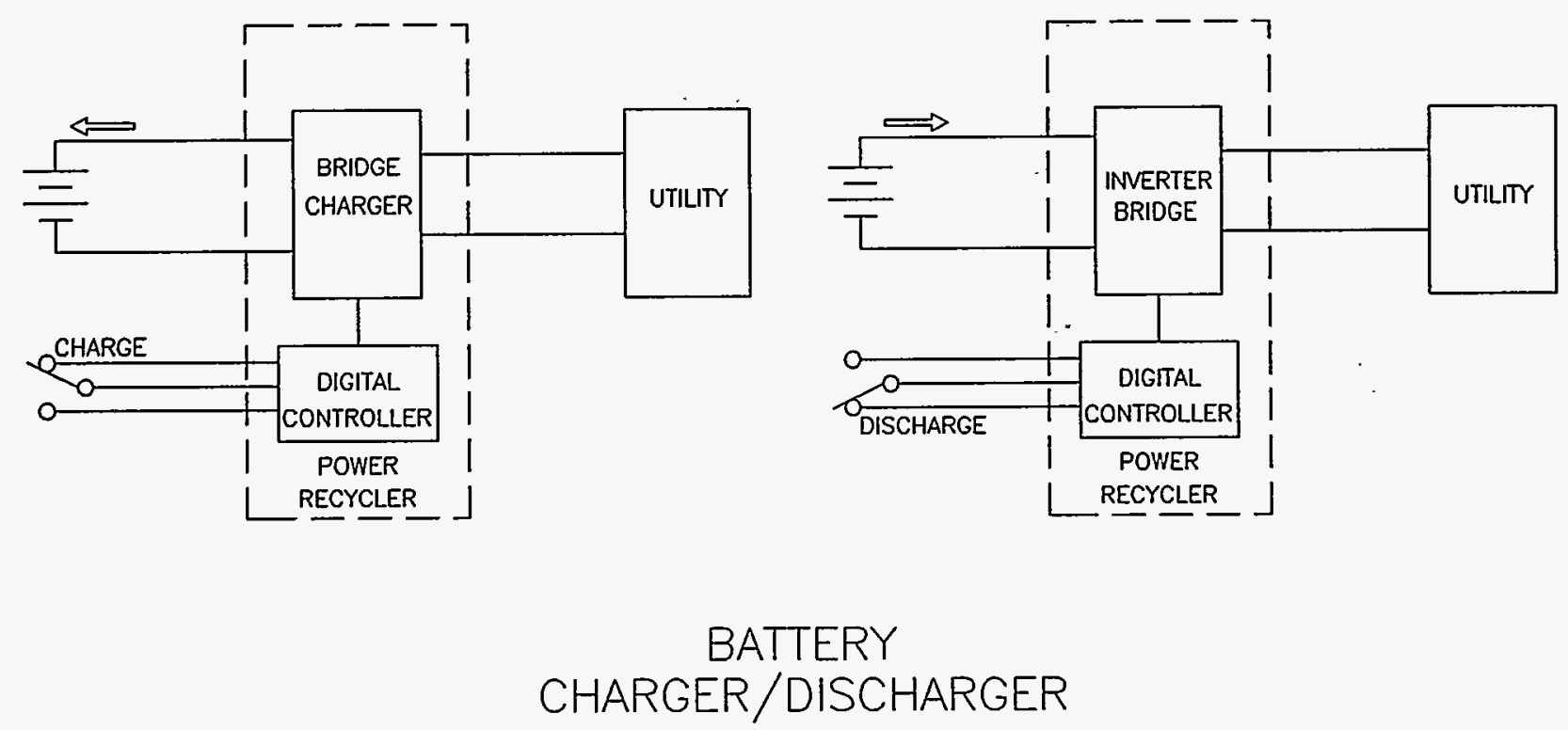


\section{CONCLUSION}

Research and development under the U. S. Department of Energy SBIR Grant No. DE-FG05-90ER80869 resulted in new cost-competitive products for the entire spectrum of photovoltaic power conditioning equipment from residential with utility grid tie to three-phase utility installations. A product line that provides energy conservation for battery, dc and uninterruptible power supply, and fuel cell testing has also evolved; the Power Recycler returns otherwise wasted test power to the utility grid.

With an ASIC and microprocessor as key control elements, new levels of reliability, safety, and power quality have been reached. For the protection of utility linemen, when the utility power goes off the sunverter is off and double disconnected in 12 milliseconds.

\section{REFERENCES}

1. Dunlop, James P., Craig Maytrott and Leighton Demetrius, "Performance Evaluation of Abacus Controls 5kVA Grid Interactive Inverter," FSEC-CR-503-92, Florida Solar Energy Center, June 23, 1992

2. O'Sullivan, George, "Solar Array Controller optimizes Cogeneration," Power Quality Magazine, April-June 1992, p.61

3. Gokhale, Kalyan P., Atsuo Kawamura, and Richard G. Hoft, "Dead Beat Microprocessor Control of PWM Inverter for Sinusoidal output Waveform Synthesis," IEEE Transactions on Industry Applications, Vol IA-23 No.5, September/October 1987, pp. 901-910

4. Mohan, Ned, Tore M. Undeland and William P. Robbins, "Harmonic Standards and Recommended Practices," Power Electronics: Converters, Applications, and Design, John Wiley \& Sons, 1989, pp. 411-414

5. O'Sullivan, George, "Bimode UPS cuts system complexity, Improves Reliability," PCIM Magazine, December 1988, p.42

6. Bower, Ward, and George O'Sullivan, "Bimode Uninterruptible Power Supply Compatibility in Renewable Hybrid Energy Systems," IEEE AES Magazine, August 1990, p.16 


\section{SUNVERTERS FOR PHOTOVOLTAIC APPLICATION Single Phase and Three Phase, 50 and $60 \mathrm{~Hz}$}

Cogenerates power into utility lines for Residential, Industrial, Government and Utility installations.

The new inverters, trademarked SUNVERTER, span the power range from $5 \mathrm{~kW}$ for residential use to $50 \mathrm{~kW}$ for commercial centers. The unit converts the wide range of $D C$ voltages from a photovoltaic array to a precise $A C$ voltage and applies the power to the utility line. No storage device, such as a battery, is needed. If more power is produced than is being consumed locally, the power is supplied to the utility grid.
During recent years, the application of photovoltaic equipment has centered on third world countries where alternative sources of electricity were not available. With the increase in environmental awareness by a majority of the world's population, photovoltaics is receiving renewed attention. This product family is also available for standalone applications.

\section{Advanced Features \\ - MaxPowerTracking To Optimize Use of Solar Energy \\ - Fast Response Through Sample Data Control System \\ - Microprocessor/ASIC Controlled
- High Accuracy
- No Adjustments Necessary
- Minimum Parts Count
- IGBT Power Stage

\section{INPUT}

See table below

\section{UTILITY VOLTAGE}

Single Phase; 240 VAC, $+8 \%,-12 \%$

Three Phase; $277 / 480,+8 \%,-12 \%$

\section{OUTPUT POWER}

See table below

EFFICIENCY

92\% Typical

\section{TURN-ON CHARACTERISTICS}

Bumpless turn-on at zero voltage crossover

\section{TARE POWER}

See table below

\section{SPECIFICATIONS}

\section{AMBIENT TEMPERATURE}

0 to 40 degrees $C$

\section{SPEED OF RESPONSE}

400 Microseconds

SHUTDOWN PROTECTION
Loss of Utility
Utility Voltage High
Utility Voltage Low
Loss of Phaselock
Array Voltage High
Array Voltage Low
Utility Current High
Utility Current Reversed
High Temperature

MAX POWER TRACKING

$1 \%$ Accuracy above $300 \mathrm{~W}$

CURRENT RIPPLE TO ARQRAY $3 \%$ RMS at $120 \mathrm{~Hz}$

CURRENT TO UTILITY THD

$5 \%$ of Full Load Current

POWER FACTOR TO UTILITY .99 Minimum

EMI PROTECTION

RFI Filter on Input and Output

HUMIDITY

90\% Non Condensing

\begin{tabular}{|c|c|c|c|c|c|c|c|c|c|c|c|c|}
\hline MODEL\#\# & $\begin{array}{l}\text { POWER } \\
\text { LEVEL }\end{array}$ & $\begin{array}{l}\text { NO. OF } \\
\text { PHASES }\end{array}$ & FREQ. & $\begin{array}{l}\text { NOMENAL } \\
\text { INPUT } \\
\text { WLTAGE }\end{array}$ & $\begin{array}{l}\text { MINIMUM } \\
\text { INPUT } \\
\text { WLTAGE }\end{array}$ & $\begin{array}{l}\text { MININUM } \\
\text { INPUT } \\
\text { VOLTAGE }\end{array}$ & $\begin{array}{c}\text { COLD } \\
\text { START } \\
\text { WOLTAGE }\end{array}$ & $\begin{array}{l}\text { HEIGHT } \\
\text { INCHES }\end{array}$ & $\begin{array}{l}\text { WIDTH } \\
\text { INCHES }\end{array}$ & $\begin{array}{l}\text { DEPTH } \\
\text { INCHES }\end{array}$ & WEIGHT & $\begin{array}{l}\text { TARE } \\
\text { POWER }\end{array}$ \\
\hline $753-4-200$ & 5000 & 1 & 60 & 200 & 160 & 240 & 300 & 20 & 16 & 14 & 160 & 106 \\
\hline $753-3-200$ & 5000 & 1 & 50 & 200 & 160 & 240 & 300 & 20 & 16 & 14 & 160 & 106 \\
\hline $7173-4-200$ & 17000 & 1 & 60 & 200 & 160 & 240 & 300 & 36 & 30 & 20 & 480 & 420 \\
\hline $7173-3-200$ & 17000 & 1 & 50 & 200 & 160 & 240 & 300 & 36 & 30 & 20 & 500 & 420 \\
\hline $7158-4-200$ & 15000 & 3 & 60 & 200 & 160 & 240 & 300 & 30 & 30 & 12 & 520 & 317 \\
\hline $7158-3.200$ & 15000 & 3 & 50 & 200 & 160 & 240 & 300 & 30 & 30 & 12 & 540 & 317 \\
\hline $759-4-200$ & 50000 & 3 & 60 & 200 & 160 & 240 & 300 & 72 & 60 & 24 & 1500 & 1260 \\
\hline $759-3.200$ & 50000 & 3 & 50 & 200 & 160 & 240 & 300 & 72 & 60 & 24 & 1600 & 1260 \\
\hline
\end{tabular}

Inverters operating independent of utility also available
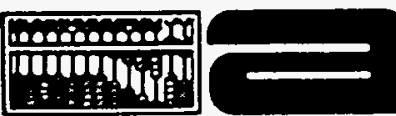

abacus controls inc.

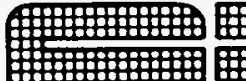

盟

Somerville, N.J. 08876

FAX: 908-526-6866

908-526-6010
Bulletin 926 


\section{Distribution:}

6218 W.I. Bower $(400)$

7141 Technical Library (5)

7151 Technical Publications

7213-2 Document Processing DOE/OSTI (10)

8523-2 Central Technical Files 